\title{
Tingkat Kebisingan pada Angkutan Umum Jalur Teling-Pusat Kota Manado
}

\author{
Marlisha C. B. Liono, ${ }^{1}$ Olivia C. P. Pelealu, ${ }^{2}$ Steward K. Mengko ${ }^{2}$
}

\author{
${ }^{1}$ Program Studi Pendidikan Dokter Fakultas Kedokteran Universitas Sam Ratulangi Manado \\ ${ }^{2}$ Bagian/SMF Telinga Hidung Tenggorok-Bedah Kepala Leher Fakultas Kedokteran \\ Universitas Sam Ratulangi / RSUP Prof. Dr. R. D. Kandou Manado \\ Email: marlisaliono@yahoo.com
}

\begin{abstract}
Noise is all unwanted sounds that can cause discomfort feeling or hearing disturbance if be exposed for long enough. Moreover, it can disturb the surrounding environment due to the generated noise. In Manado, many public transportation have audio system to play high volume music, therefore, causing noise. This study was aimed to determine the level of noise in public transportation of Teling to Manado downtown track. This was a descriptive and observational study with a cross sectional design. Samples were 100 vehicles of Teling to Manado downtown track. Noise measurement was performed by using a sound level meter. Data were analyzed by using Microsoft Office Excel. The results obtained 56 vehicles with audio systems and 44 vehicles without audio systems. Among 56 vehicles with audio systems, there were 47 vehicles that had noise levels above the noise threshold value which was 86.05$114.15 \mathrm{~dB}$ with exposure time about 8-16 hours. Meanwhile, among 44 vehicles without audio system, there were only 2 vehicles that had noise levels above threshold value which was 88.05-91.8 dB with exposure time about 10-12 hours. In conclusion, there were $49 \%$ of public vehicles had noise level above the threshold value.
\end{abstract}

Keywords: noise; public transportation

\begin{abstract}
Abstrak: Kebisingan adalah semua bunyi yang tidak dikehendaki yang dapat menimbulkan ketidaknyamanan atau gangguan pendengaran jika terpapar lama. Selain itu kebisingan dapat juga mengganggu lingkungan sekitar. Di Kota Manado, banyak angkutan umum yang menggunakan sistem audio untuk memutar musik dengan volume yang tinggi sehingga menimbulkan kebisingan. Penelitian ini bertujuan untuk mengetahui tingkat kebisingan pada angkutan umum jalur Teling-Pusat Kota Manado. Jenis penelitian ialah observasional deskriptif dengan desain potong lintang. Sampel berjumlah 100 kendaraan pada jalur Teling-Pusat Kota Manado. Pengukuran kebisingan dilakukan menggunakan alat Sound Level Meter. Data diolah dengan Microsoft Office Excel. Hasil penelitian mendapatkan 56 kendaraan yang menggunakan sistem audio dan 44 kendaraan tidak menggunakan sistem audio. Pada 56 kendaraan yang menggunakan sistem audio terdapat 47 kendaraan dengan tingkat kebisingan di atas nilai ambang batas kebisingan yaitu $86,05-114,15$ dB dengan waktu terpapar selama 816 jam sedangkan pada 44 kendaraan yang tidak menggunakan sistem audio terdapat 2 kendaraan yang memiliki tingkat kebisingan di atas nilai ambang batas kebisingan yaitu 88,05-91,8 dB dengan waktu terpapar selama 10-12 jam. Simpulan penelitian ini ialah terdapat $49 \%$ kendaraan umum memiliki kebisingan di atas nilai ambang batas.
\end{abstract}

Kata kunci: kebisingan, angkutan umum

\section{PENDAHULUAN}

Kebisingan adalah semua bunyi yang tidak dikehendaki sehingga menimbulkan ketidaknyamanan atau gangguan pendengaran. Kebisingan merupakan salah satu faktor yang menyebabkan masalah kese- 
hatan lingkungan. Intensitas bising yang melebihi nilai ambang batas dapat menyebabkan timbulnya gangguan kesehatan, yaitu gangguan pendengaran. ${ }^{1,2}$

Nilai ambang batas kebisingan (NAB) berdasarkan waktu yaitu 1 sampai 8 jam perhari untuk intensitas kebisingan antara $85 \mathrm{~dB}$ dan $94 \mathrm{~dB}$. Pada satuan menit, waktu yang telah ditetapkan ialah 0,94 sampai 30 menit perhari untuk intensitas kebisingan antara $97 \mathrm{~dB}$ sampai $112 \mathrm{~dB}$ sedangkan dalam satuan detik, waktu yang telah ditetapkan ialah 0,11 sampai 28,12 detik perhari untuk intensitas kebisingan antara $115 \mathrm{~dB}$ sampai $139 \mathrm{~dB}$. Nilai ambang batas berdasarkan tempat yang telah diizinkan antara lain 50-55 dB di kawasan terbuka hijau, rumah sakit, pemukiman, sekolah, dan tempat ibadah sedangkan untuk perkantoran, kawasan industri dan fasislitas umum lainnya antara 60-70 dB. ${ }^{3,4}$

Transportasi adalah perpindahan barang atau manusia dari satu tempat ke tempat lainnya dengan menggunakan sebuah kendaraan yang digerakkan oleh manusia atau mesin. Di zaman modern ini, alat transportasi berperan penting dalam kehidupan manusia untuk melakukan berbagai aktivitas sehari-hari. Namun, alat transportasi juga dapat memberikan dampak negatif bagi manusia dikarenakan berbagai bunyi yang dihasilkan sehingga menimbulkan kebisingan yang dapat mengganggu kesehatan pendengaran manusia.

Menurut World Health Organization (WHO), diperkirakan terdapat 360 juta $(5.3 \%)$ orang di dunia mengalami gangguan pendengaran yang terdiri dari 328 juta $(91 \%)$ orang dewasa (183 juta laki-laki dan 145 juta perempuan) dan 32 juta (9\%) anak-anak. Prevalensi gangguan meningkat seiring dengan pertambahan usia. Prevalensi gangguan pendengaran pada orang di atas usia 65 tahun bervariasi dari $18-50 \%$ di seluruh dunia. Berdasarkan provinsi, prevalensi gangguan pendengaran tertinggi terdapat di Nusa Tenggara Timur $(3,7 \%)$, Sulawesi Utara $(2,4 \%)$, dan terendah di Banten (1,6\%), sedangkan prevalensi ketulian tertinggi ditemukan di Maluku $(0,45 \%)$, Sulawesi Utara $(0,12 \%)$, terendah di Kalimantan Timur (0,03\%). ${ }^{6,7}$

Di Kota Manado, banyak angkutan umum berupa mobil penumpang (mikrolet) menghasilkan suara-suara yang mengganggu kenyamanan lingkungan hidup baik karena bunyi klakson, suara knalpot akibat penekanan pedal gas yang berlebihan, suara mesin kendaraan, maupun penggunaan audio sistem dalam angkutan umum (mikrolet) dengan volume yang sangat tinggi sehingga menyebabkan kebisingan yang dapat mengakibatkan gangguan kesehatan terutama gangguan pendengaran. Gangguan pendengaran yang timbul bukan hanya bisa dialami oleh penumpang mikrolet tetapi juga oleh sopir mikrolet yang terpapar kebisingan setiap hari.

\section{METODE PENELITIAN}

Jenis penelitian yang digunakan ialah deskriptif observasional, dengan desain potong lintang. Sample penelitian menggunakan total sampling yaitu mikrolet jalur Teling - Pusat Kota Manado.

\section{HASIL PENELITIAN}

Sampel yang didapatkan berjumlah 100 buah angkutan umum jalur TelingPusat Kota Manado. Seluruh sampel dikendarai oleh sopir yang berjenis kelamin lakilaki.

Tabel 1 memperlihatkan penggunaan sistem audio yang cukup lengkap (memiliki radio tape dan minimal 1 speaker) pada mobil angkutan umum jalur Teling-Pusat Kota Manado. Dari 100 kendaraan angkutan umum yang diperiksa, terdapat 56 kendaraan angkutan umum yang menggunakan sistem audio dan 44 kendaraan yang tidak menggunakan sistem audio.

Tabel 1. Karakteristik penggunaan audio angkutan umum jalur Teling-Pusat Kota Manado

\begin{tabular}{ccc}
\hline Sistem audio & Jumlah & \% \\
\hline Menggunakan & 56 & $56 \%$ \\
Tidak menggunakan & 44 & $44 \%$ \\
\hline
\end{tabular}

Tabel 2 memperlihatkan hasil pengukuran tingkat kebisingan dari 44 kendaraan angkutan umum yang tidak menggunakan 
audio. Didapatkan 42 kendaraan (96\%) yang memiliki kebisingan normal yaitu 64,9-81,55 dB dan 2 kendaraan (4\%) yang memiliki kebisingan di atas nilai normal yaitu $88,05-91,8 \mathrm{~dB}$.

Tabel 2. Pengukuran tingkat kebisingan pada kendaraan yang tidak menggunakan sistem audio

\begin{tabular}{cccc}
\hline $\begin{array}{c}\text { Nilai } \\
\text { kebisingan } \\
\text { (dB) }\end{array}$ & Jumlah & $\begin{array}{c}\text { Lama } \\
\text { bekerja } \\
\text { dalam } \\
\text { sehari }\end{array}$ & $\%$ \\
\hline $64,9-81,55$ & 42 & $7-16$ jam & $96 \%$ \\
88,05 & 1 & 12 jam & $2 \%$ \\
91,8 & 1 & 10 jam & $2 \%$ \\
\hline
\end{tabular}

Tabel 3 dan Gambar 1 memperlihatkan hasil pengukuran tingkat kebisingan pada angkutan umum yang menggunakan sistem audio diklasifikasikan berdasarkan Permenakertrans No.13/Men/X/2011 ${ }^{3}$

Tabel 3. Pengukuran tingkat kebisingan pada kendaraan yang menggunakan sistem audio

\begin{tabular}{cccc}
\hline $\begin{array}{c}\text { Nilai } \\
\text { kebisingan } \\
(\text { dB })\end{array}$ & $\begin{array}{c}\text { Jumlah } \\
\text { kendaraan }\end{array}$ & $\begin{array}{c}\text { Lama } \\
\text { bekerja } \\
\text { per hari }\end{array}$ & $\%$ \\
\hline $73,3-84,05$ & 9 & $8-14$ jam & 16 \\
$86,05-87,8$ & 2 & 10 jam & 4 \\
$89,15-91,1$ & 7 & $12-16$ jam & 12 \\
$91,9-94,15$ & 5 & $10-12$ jam & 9 \\
$94,8-96,15$ & 7 & $8-12$ jam & 12 \\
$98,7-100,5$ & 9 & $8-15$ jam & 16 \\
$101,05-103,55$ & 8 & $9-15$ jam & 14 \\
$104,1-105,45$ & 6 & 12 jam & 11 \\
108,35 & 1 & 12 jam & 2 \\
$111,9-114,15$ & 2 & 12 jam & 4 \\
\hline
\end{tabular}

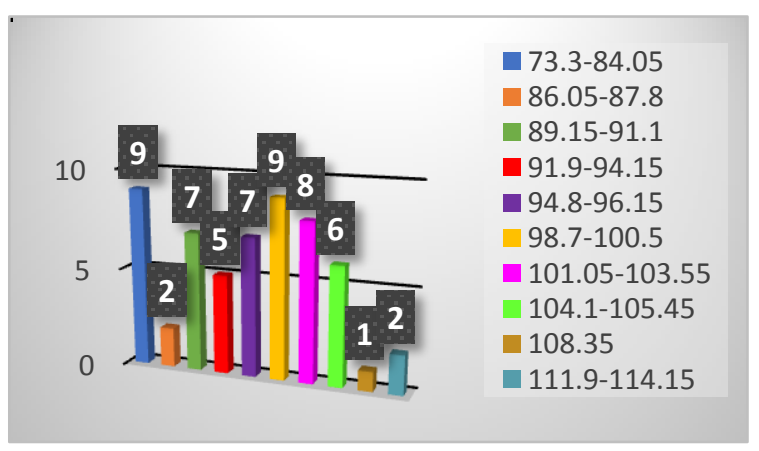

Gambar 1. Distribusi hasil pengukuran kendaraan yang memiliki sistem audio.
Hasil pengukuran tingkat kebisingan pada kendaraan angkutan umum yang menggunakan sistem audio (56 kendaraan) mendapatkan 9 kendaraan yang memiliki kebisingan normal yaitu 73,3-84,05 dB; 14 kendaraan yang memiliki kebisingan di atas nilai normal yaitu $86,05-94,15 \mathrm{~dB}$; dan 33 kendaraan yang memiliki kebisingan tinggi yaitu 94,8-114,15 dB.

\section{BAHASAN}

Secara umum kebisingan merupakan bunyi yang tidak diinginkan atau gema akustik yang tidak menyenangkan. Bising dengan intensitas di atas $85 \mathrm{~dB}$ lebih dapat mengakibatkan kerusakan reseptor pendengaran korti telinga dalam. ${ }^{5,8}$

Berdasarkan hasil penelitian yang dilakukan pada 100 kendaraan angkutan umum jalur Teling-Pusat Kota Manado didapatkan 56 kendaraan $(56 \%)$ yang memiliki sistem audio dalam kendaraan angkutan umum dan 44 kendaraan (44\%) yang tidak memiliki sistem audio dalam kendaraan angkutan umum. Hasil pengukuran intensitas kebisingan pada 56 kendaraan yang memiliki sistem audio mendapatkan 9 kendaraan dengan tingkat kebisingan rerata masih di bawah nilai ambang batas menurut Permenakertrans No.13/Men/X/ 2011; di atas nilai ambang batas kebisingan 86,05-94,15 dB sebanyak 14 kendaraan; dan kebisingan tinggi di atas nilai ambang batas kebisingan 94,8-114,15 dB sebanyak 33 kendaraan. ${ }^{3,4}$

Pada pengukuran intensitas kebisingan dari 44 kendaraan yang tidak memiliki sistem audio dalam kendaraannya, tingkat kebisingan yang diukur bersumber dari mesin kendaraan tersebut. Didapatkan hasil tingkat kebisingan di bawah nilai ambang kebisingan 64,9-81,55 dB sebanyak 42 kendaraan dan kebisingan di atas nilai ambang kebisingan 88,05-91,8 dB sebanyak 2 kendaraan. Kebisingan pada kendaraan yang tidak memiliki sistem audio bisa disebabkan oleh berbagai hal misalnya suara klakson angkutan umum, laju kendaraan, serta komposisi kendaraan seperti knalpot racing, pembakaran mesin, pergesekan ban, dan suara rem angin., ${ }^{3,12}$ 
Pengukuran lama bekerja dalam sehari pada 56 kendaraan angkutan umum yang memiliki sistem audio dengan waktu pemaparan perhari yang diizinkan menurut Permenakertrans No.13/Men/X/2011, yaitu pada kebisingan di bawah nilai ambang batas kebisingan 73,3-84,05 dB memiliki waktu bekerja 8-14 jam dalam sehari dengan waktu pemaparan perhari yang diizinkan maksimal selama 8 jam; kebisingan di atas nilai ambang batas kebisingan 86,05-94,15 dB memiliki waktu bekerja 10-16 jam dalam sehari dengan waktu pemaparan perhari yang diizinkan maksimal selama 1-4 jam; dan kebisingan tinggi di atas nilai ambang batas kebisingan 94,8-114,15 dB memiliki waktu bekerja 815 jam dalam sehari dengan waktu pemaparan perhari yang diizinkan selama 0,94-30 menit. ${ }^{3}$

Pengukuran lama bekerja dalam sehari pada 44 kendaraan angkutan umum yang tidak memiliki sistem audio mendapatkan pada kebisingan dibawah nilai ambang batas kebisingan yaitu 64,9-81,55 dB memiliki waktu bekerja 7-16 jam dalam sehari dengan waktu pemaparan perhari yang diizinkan selama 8 jam dan kebisingan diatas nilai ambang batas kebisingan yaitu 88,05-91,8 dB memiliki waktu bekerja 10-12 jam dalam sehari dengan waktu pemaparan perhari yang diizinkan selama 2-4 jam dimana batas waktu paparan terhadap kebisingan yang diizinkan perhari mengacu pada Permenakertrans No.13/Men/X/2011. ${ }^{3}$

Kebisingan menyebabkan terjadinya kerusakan sel rambut luar koklea karena paparan bising terus menerus dengan jangka waktu yang lama. Stereosilia pada sel-sel rambut luar koklea akan menjadi atrofi bahkan mati kemudian digantikan jaringan parut sehingga mengurangi respon terhadap stimulasi suara. Dengan semakin luasnya kerusakan sel-sel rambut luar koklea dapat terjadi degenerasi saraf yang dapat sampai di nukleus pendengaran pada batang otak. Kerusakan sel-sel rambut luar koklea ini menyebabkan tuli sensori-neural. Ketulian terjadi biasanya di kedua telinga dan jarang menyebabkan tuli derajat yang sangat berat, tetapi mengakibatkan penurunan kemampuan pendengaran. ${ }^{11}$

Pada penelitian ini didapatkan bahwa intensitas kebisingan berkisar pada 86,05$114,15 \mathrm{~dB}$ yang berarti nilai ini berada di atas nilai ambang batas kebisingan yang diperbolehkan Permenakertrans No.13/ $\mathrm{Men} / \mathrm{X} / 2011$ yaitu $85 \mathrm{~dB}$. Bila terpapar bising di atas batas yang diperbolehkan dalam waktu tertentu dapat menyebabkan kerusakan atau penurunan fungsi organ pendengaran khususnya organ korti sehingga dapat mengakibatkan terjadinya kerusakan dan penurunan fungsi pendengaran pada sopir-sopir angkutan umum mikrolet jalur Teling-Pusat Kota Manado. ${ }^{3,11}$

Penelitian oleh Listyaningrum ${ }^{13}$ terhadap tenaga kerja di PT Sekar Bengawan Kabupaten Karanganyar menyatakan bahwa terdapat perbedaan intensitas kebisingan pada ruang colour mixer $(94 \mathrm{~dB})$ dan ruang tracer $(80,6 \mathrm{~dB})$. Hasil pemeriksaan audiometri pada $65 \%$ pekerja yang bekerja di ruang colour mixer mengalami penurunan fungsi pendengaran baik telinga kanan maupun kiri. Hal yang sama juga dipaparkan pada penelitian yang dilakukan oleh Tarigan ${ }^{9}$ terhadap tenaga kerja Bagian Pengolahan Kelapa Sawit di PTPN II Tanjung Garbus-Pagar Merbau yang mendapatkan dari total sampel 32 tenaga kerja, $50 \%$ terpapar kebisingan mesin di atas $85 \mathrm{~dB}$ dan sisanya terpapar kebisingan di bawah $85 \mathrm{~dB}$. Kelompok yang terpapar kebisingan di atas $85 \mathrm{~dB}$ menunjukan rasio jumlah tenaga kerja yang mengalami penurunan kemampuan pendengaran ringan dan sedang lebih banyak dibandingkan dengan yang normal, sebaliknya kelompok yang terpapar kebisingan di bawah $85 \mathrm{~dB}$ menunjukkan rasio jumlah tenaga kerja yang tidak terganggu kemampuan pendengarannya lebih banyak dibanding yang mengalami penurunan kemampuan pendengaran baik ringan maupun sedang. Menurut Cunningham et al $^{10}$ sekitar 104 juta orang di negara Amerika Serikat terkena kebisingan yang bisa menyebabkan gangguan pendengaran dan 1 dari 4 orang dewasa di Amerika Serikat memiliki gangguan pendengaran yang terukur disebabkan 
oleh paparan kebisingan yang berbahaya. Bahkan di antara orang-orang yang melaporkan bahwa pendengaran mereka sangat baik atau baik, hampir $20 \%$ memiliki bukti pemeriksaan audiometri yang menunjukkan adanya gangguan pendengaran yang disebabkan oleh kebisingan.

Pada penelitian yang dilakukan oleh Pristianto $^{12}$ mengenai kebisingan akibat aktivitas transportasi di Jalan Ahmad Yani Kota Sorong, diperoleh tingkat kebisingan lalu lintas kendaraan pada Jalan Ahmad Yani dengan 2 (dua) titik lokasi berbeda telah melampaui standar baku mutu yang di tetapkan menurut Keputusan Menteri Negara Lingkungan Hidup No. KEP48/ MENLH/11/1996 untuk kawasan perumahan, rumah sakit, tempat ibadah, dan sarana pendidikan. Faktor penyebab kebisingan lalu lintas tersebut bersumber dari kondisi jalan yang terdapat tanjakan, suara klakson angkutan umum, laju kendaraan, serta komposisi kendaraan seperti knalpot racing, pembakaran mesin, pergesekan ban, dan suara rem angin. ${ }^{12}$

Bila dibandingkan hasil penelitian ini dengan hasil beberapa penelitian yang telah dipaparkan, maka perlu dilakukan penelitian lanjut terhadap para supir kendaran angkutan umum dengan melibatkan pihakpihak yang berwewenang agar tidak dapat dilakukan upaya pencegahan dan tidak berlanjut dengan terjadinya gangguan pendengaran permanen.

\section{SIMPULAN}

Pada angkutan umum jalur TelingPusat Kota Manado didapatkan 56\% yang memiliki sistem audio dan $44 \%$ yang tidak memiliki sistem audio. Sebagian besar kendaraan dengan sistem audio memiliki kebisingan di atas nilai ambang batas kebisingan. Walaupun demikian, beberapa kendaraan yang tidak memiliki sistem audio juga memiliki kebisingan di atas nilai ambang batas kebisingan.

Bagi peneliti lanjut, disarankan untuk melakukan pemeriksaan audiometri dan otoaccoustic emission pada sopir angkutan umum tersebut dan juga pada jalur-jalur yang lain di Kota Manado.
Regulasi peraturan pemerintah yang mengatur tentang nilai batas kebisingan yang diizinkan pada angkutan umum di Kota Manado perlu disosialisasikan kepada masyarakat.

\section{Konflik Kepentingan}

Penulis menyatakan tidak terdapat konflik kepentingan dalam studi ini.

\section{DAFTAR PUSTAKA}

1. Keputusan Menteri Kesehatan Republik Indonesia Nomor 1405/MENKES/SK/ $\mathrm{XI} / 2002$ tentang persyaratan kesehatan lingkungan kerja perkantoran dan industri.

2. Kusumawati I. Hubungan tingkat kebisingan di lingkungan kerja dengan kejadian gangguan pendengaran pada pekerja di PT X Tahun 2012 [Skripsi]. Depok: Universitas Indonesia. 2012.

3. Peraturan Menteri Tenaga Kerja dan Transmigrasi No. Per.13/MEN/X/2011 tahun 2011 tentang nilai ambang batas faktor fisika dan faktor kimia di tempat kerja.

4. Keputusan Menteri Negara Lingkungan Hidup Nomor Kep-48/MENLH/11/1996 tentang baku tingkat kebisingan

5. Soepardi EA, Iskandar N, Bashiruddin J, Restuti RD. Buku Ajar Ilmu Kesehatan Telinga Hidung Tenggorok Kepala \& Leher. Jakarta: Balai Penerbit FK UI, 2007.

6. Korompis AM, Tumbel RE, Mengko SK. Kesehatan telinga di Sekolah Dasar Negeri 11 Manado. e-CliniC. 2018; 6(1):46-9.

7. Haurissa MP, Mengko SK, Palandeng OI. Pengaruh paparan bising terhadap ambang pendengaran siswa SMK Negeri 2 Manado jurusan teknik konstruksi batu beton. e-CliniC. 2014; 2(1).

8. Sliwinska-Kowalska M, Zaborowski K. WHO environmental noise guidelines for the European region: A systematic review on environmental noise and permanent hearing loss and tinnitus. Int $\mathrm{J}$ Environ Res Public Health. 2017;14(10):1.

9. Tarigan LO. Gambaran Intensitas Kebisingan dan Kemampuan Pendengaran pada Tenaga Kerja Bagian Pengolahan Kelapa Sawit di PTPN II Tanjung Garbus-Pagar Merbau Tahun 2017 
20 e-CliniC, Volume 8, Nomor 1, Januari-Juni 2020, hlm. 15-20

[Skripsi]. Medan Universitas Sumatra Utara; 2018.

10. Cunningham LL, Tucci DL. Hearing Loss in Adults. N Engl J Med [Internet]. 2017;377(25):2465-73.

11. Lintong F. Gangguan Pendengaran Akibat Bising. J Biomedik. 2013;1(2)::84-5.

12. Pristianto H. Analisa kebisingan akibat aktivitas transportasi di Jalan Ahmad Yani Kota Sorong. Sorong: Fakultas
Teknik Universitas Muhammadiyah Sorong; 2016. DOI 10.17605/OSF. IO/YDEZS

13. Listyaningrum AW. Pengaruh Intensitas kebisingan terhadap ambang dengar pada tenaga kerja di PT Sekar Bengawan Kabupaten Karangnyar. 2011;1-67 [Skripsi]. Surakarta: Universitas 11 Maret; 2011. 